\title{
Historical analysis of storm events: Case studies in France, England, Portugal and Italy
}

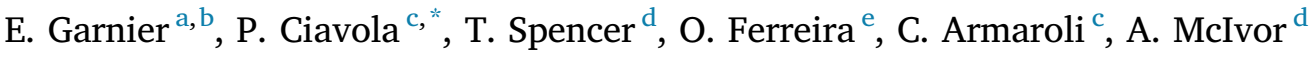 \\ ${ }^{a}$ LIttoral ENvironnement et Sociétés (LIENSs) - UMR 7266, La Rochelle, France \\ ${ }^{\mathrm{b}}$ UMR Chrono-Environnement, Besançon, France \\ ${ }^{\mathrm{c}}$ Department of Physics and Earth Sciences, University of Ferrara, Ferrara, Italy \\ ${ }^{\mathrm{d}}$ CCRU, Department of Geography, University of Cambridge, Cambridge, UK \\ e CIMA, University of Algarve, Faro, Portugal
}

\section{A R T I C L E I N F O}

\section{Keywords:}

Coastal storms

Storm surges

Historical archives

\begin{abstract}
A B S T R A C T
An historical analysis of the occurrence of storms and their damage intensity is presented. The work analysed historical large-scale events from The Middle Ages to the 1960s at case study sites along the coasts of North Norfolk (UK); Charente-Maritime and Vendée (France); Cinque Terre-Liguria coast (Italy); Emilia-Romagna coast (Italy) and Ria Formosa (Portugal). The work presented here used a database of events built by the RISC-KIT project, including the characteristics of the storms as well as recorded human impacts. Historical records can provide an important test bed to complement the statistical analysis of the return period of events based on measurements and provide important indicators of past events and their impact that are no longer within the historical memories of resident populations and coastal managers.
\end{abstract}

\section{Introduction}

Severe storms have historically affected European coastlines and the impact of each storm has been evaluated in different ways in different countries, often using local socio-economic impact criteria (e.g. loss of lives and damage to property). Although the Xynthia storm was the largest European coastal disaster of the last 50 years, with 47 people killed in France alone, similar events have previously impacted Europe. The 1953 storm surge in the southern North Sea, which resulted in over 2000 deaths and extensive flooding across The Netherlands, England, Belgium and Scotland, led to strengthened flood defences and the development of modern flood warning systems. Even further back in history, the impact of the very extreme storm of $1634 \mathrm{AD}$ devastated the Wadden Sea coast, causing thousands of deaths (Fruergaard et al., 2013), while the Christmas night flood of 24-25 December 1717 resulted in at least 11,000 fatalities on North Sea coasts (Lamb, 1991).

Historical records can provide an important source of information to help improve coastal risk studies. Camuffo et al. (2000), using historical sources, managed to correlate events across the northern Mediterranean during the last millennium. Garnier and Surville (2011) proved that the part of France hit by storm Xynthia (2012) was historically exposed to sea flooding; however, the presence of the embankment that protected the flooded urban areas gave a "false sense of security", as the condition of the century-old dikes was not known. Moreover, this "false sense of security" was strengthened thanks to the lack and/or loss of "historical memory" of the impact of historical extreme events. Indeed, the population and their managers had forgotten about the dangers of high intensity events within one century. This "historical memory" may possibly be revived through the use of historical documents and records. Thus there is scope for using historical records in a comprehensive way, recreating complete time series of extreme events through a mixture of data compilation and numerical reconstruction.

This philosophy paved the way for the RISC-KIT project (Resilienceincreasing Strategies for Coasts - Toolkit), which aimed to develop methods, tools and management approaches, linking with EU and national policies and taking the historical dimension into consideration (Van Dongeren et al., this issue). Within this framework, the historical research undertaken at five case study sites (Fig. 1: North Norfolk, Ria Formosa, Bocca di Magra, Porto Garibaldi, and la Faute-sur-Mer) discusses the extent to which it is correct to describe a recent disaster (e.g. one that has occurred in the last 20-30 years) as an unprecedented event (i.e. one that has never happened before in the past). Rather, this paper

\footnotetext{
* Corresponding author.

E-mail addresses: egarnier.cea-cnrs@orange.fr (E. Garnier), cvp@unife.it (P. Ciavola), ts111@cam.ac.uk (T. Spencer), oferreir@ualg.pt (O. Ferreira), clara.armaroli@unife.it (C. Armaroli),alm1000@cam.ac.uk (A. McIvor).
} 

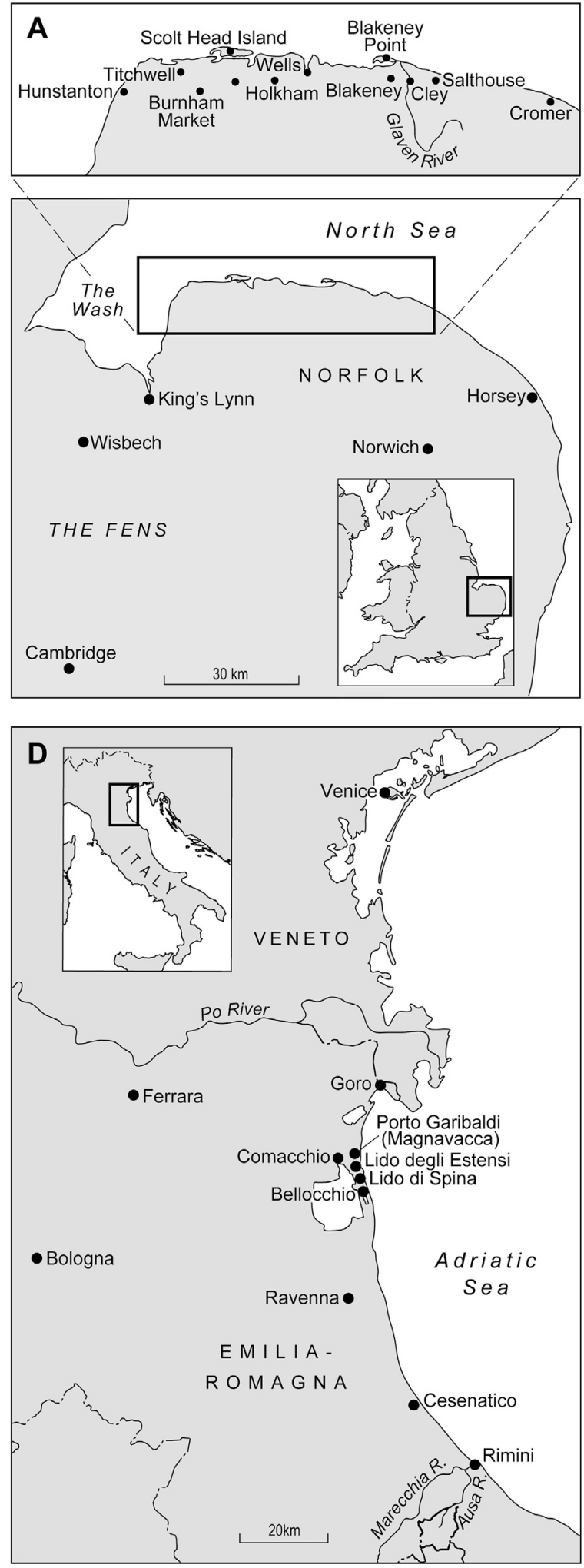
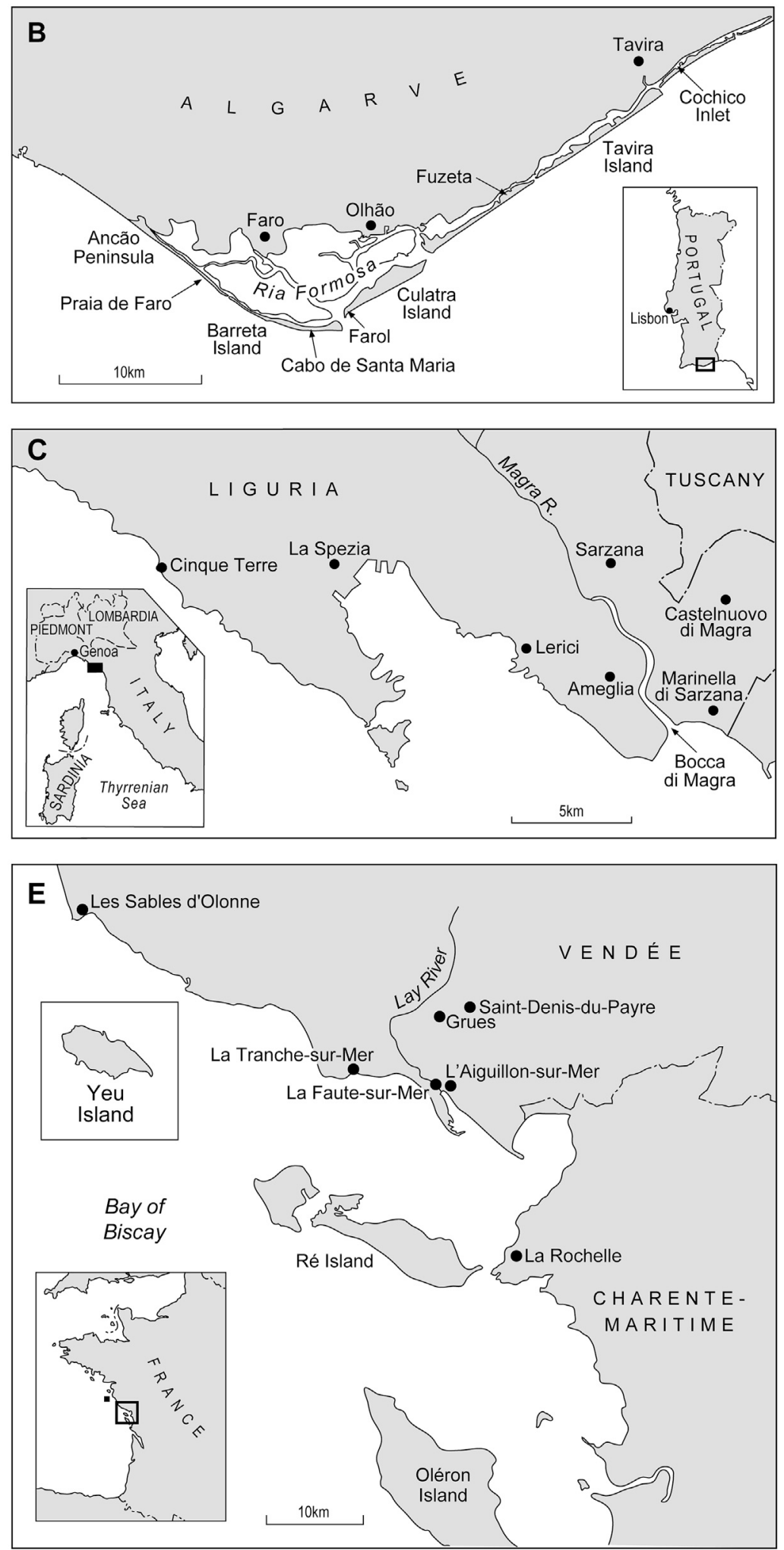

Fig. 1. Location of the study sites.

discusses the trajectory of vulnerability at these sites with the objective of showing how lessons learned, extracted from historical documentation, could have been used to better understand the risks, and thus have potentially reduced the vulnerability to extreme storm events.

How far back in time means that an event can be called 'historical'? In this context, Baart (2013; and see also Baart et al., 2011) provides an interesting classification of storm surge source materials used to define the 1:10,000 year return period event in The Netherlands. Pre-historic storms are those for which neither measurements nor written records are available; on this geological time scale surge heights can only be inferred from sedimentary and stratigraphic records. Historical storms can be identified using written or visual records. In this case the date of 
the storm is known; and at some locations the maximum water level. Finally, there are measured or modelled events in the modern era where all the key parameters are either known or can be reasonably inferred (waves, water levels, impacts).

The main aim of our analysis was to better understand the risks, and thus contribute to potentially reduce vulnerability to extreme storm events by showing lessons learned, extracted from historical documentation. For that purpose we used historical records in a comprehensive way, recreating and analysing extreme events, for five case study sites (Fig. 1: North Norfolk, Ria Formosa, Bocca di Magra, Porto Garibaldi, and La Faute-sur-Mer). We believe that, within reason, we have captured all the significant flood events that have impacted these five areas in the historical period; this information is available in detail in the RISC-KIT Storm Impact Database (http://risckit.cloudapp.net/risckit/ \#/(accessed 05.06.2017)).

\section{The case study sites (CSS)}

\subsection{North Norfolk (UK)}

The $45 \mathrm{~km}$ long North Norfolk coast (Fig. 1a), eastern England is macrotidal (mean spring tidal range of $6.6 \mathrm{~m}$ in the west at Hunstanton, reducing eastwards to $4.7 \mathrm{~m}$ at Cromer) but characterised by a moderate to low wave climate (monthly mean significant wave heights: $0.36-0.80 \mathrm{~m}$ ). The combination of high tidal range and low offshore slopes has allowed the Holocene development of extensive subtidal and intertidal mudflats and sandflats seaward of large gravel barriers (Scolt Head Island, Blakeney Point) and back-barrier mudflats, tidal channels and saltmarshes. Landward margins are characterised by reclaimed saltmarsh (freshwater marsh) and, locally, by reedbeds and sand dunes (some with plantation forest) (Spencer et al., 2015). This mosaic of habitats is recognised internationally through the North Norfolk coast Special Area of Conservation (SAC) and as a Special Protection Area (SPA)/Ramsar site. There are important bird reserves at Titchwell and Cley, which attract significant numbers of visitors. Four small river valleys make outfall at the coast. The hinterland is predominantly agricultural with small towns and villages developed around fishing settlements and former medieval ports. The shallow and relatively enclosed setting of the southern North Sea makes it susceptible to storm surges when E or SEtracking low-pressure systems interact with high spring tides. Highest Astronomical Tide reaches $4.0 \mathrm{~m}$ ODN (where the UK datum of $0.0 \mathrm{~m}$ ODN approximates to mean sea level) but surge levels can exceed $5.0 \mathrm{~m}$ ODN and cause extensive local flooding, barrier breaching and shoreline retreat when accompanied by onshore waves from a northerly direction. Some $15 \%$ of the frontage is characterised by natural defences and $50 \%$ by earth embankments ('sea walls'); with the current maintenance regime, defence design lifetime is estimated at $40-80$ years. By contrast, river flooding is estimated at moderate to low risk.

\subsection{Ria Formosa (Portugal)}

Ria Formosa (Fig. 1b) is a shallow meso-tidal coastal lagoon protected by 2 peninsulas and 5 barrier islands and located in the Algarve, southern coast of Portugal. It is about $55 \mathrm{~km}$ long and has a maximum width of about $6 \mathrm{~km}$. The embayment is characterised by large salt marshes, sandflats and a complex network of tidal channels, see Ferreira et al. (2016) for further details. The barriers have an ocean beach, dunes and sandy backbarrier (or salt marsh). Tidal range is 3.5-4 $\mathrm{m}$ on spring tides. Waves are dominant from the W-SW and although generally having low to moderate energy, high intensity storms (significant wave heights higher than $3 \mathrm{~m}$ ) occur during winter. Human occupation at the barriers is relatively recent e.g. since the 19th century (Freitas and Dias, 2013) and limited to a few settlements (Praia de Faro, Culatra, Farol, etc) in the dunes, from both fisherman and second residents' communities. The inner part of the lagoon is bordered by some of the most important towns in the Algarve, including Faro, Olhão and Tavira. The most documented coastal disaster in the region was the so-called Lisbon earthquake and tsunami of the 1st November 1755, an event that devastated the Algarve. Storms are also a frequent hazard that causes severe impacts, being responsible in the past for the destruction of islands, inlet opening, collapse of houses and damage to roads. The occupation of the barriers (islands and peninsulas), even if relatively small, has being threatened since its inception and recurrently faces coastal hazards. Tens of houses have recently (2008-2010) been destroyed by the sea but no casualties have, so far, been recorded.

\subsection{Bocca di magra (Italy)}

Bocca di Magra is a small estuary formed by the Magra River in Italy, along the border between the Liguria and Tuscany Regions, facing the Thyrrenian Sea (Fig. 1c). The upland territory of the Magra River Basin is mainly a mountain and hill area, with an absence of lowland environments, even at the mouth of the river. The lower parts of the basin are used for agricultural and industrial activities. The coastal zone is a very narrow strip of land that descends almost immediately to considerable marine depths. The marine environment is micro-tidal with a spring tidal range of about $0.3 \mathrm{~m}$. Wave direction is constrained between a direction of $200^{\circ} \mathrm{N}$ and $240^{\circ} \mathrm{N}$. From a study of Cappucci et al. (2011), the modal wave height is between 0.5 and $1 \mathrm{~m}$ and occurs $23 \%$ of the time. Waves exceeding $3 \mathrm{~m}$ occur $1 \%$ of the time. According to Aminti et al. (2002), the highest storm waves reach heights in excess of $6 \mathrm{~m}$. Beaches and coastal plains are only present to the south of the estuary while the northern side is constrained by the Cinque Terre promontory.

\subsection{Porto Garibaldi (Italy)}

Porto Garibaldi-Bellocchio is a $9 \mathrm{~km}$-long stretch of coast, located in the Ferrara and Ravenna provinces, in the region of Emilia-Romagna, northern Italy, facing the Northern Adriatic Sea (Fig. 1d). The microtidal regime of this area has a spring tide range of $0.8-0.9 \mathrm{~m}$. The wave regime is generally of low energy, with almost $65 \%$ of wave heights being less than $1 \mathrm{~m}$. Energetic storms come from the E-NE and SE. The 1in-1 year return period wave height is $3.3 \mathrm{~m}$ (Armaroli et al., 2012). The hinterland is characterised by the presence of wide lagoons, wetlands and canals. Most of the territory is extremely low-lying, with coastal elevations reaching a maximum of just $2 \mathrm{~m}$ above MSL (mean sea level), and a large part of the hinterland being below sea level. The area can be divided into a northern and southern section of almost equal lengths. The northern section is mostly urbanized and the beach is characterised by the presence of bathing establishments that provide numerous services to beach users during the summer months. Two towns, Lido degli Estensi and Lido di Spina, with a total of 2750 inhabitants, were built in this section in the 1970s and are divided by an artificial canal. The southern section of the study area meanwhile is natural and characterised by the presence of the Bellocchio marsh that is divided into two parts by an artificially created channel that connects the wetland systems with the sea. This connection is important in order to maintain water quality within the wetlands and to prevent adverse effects to aquaculture and fisheries as well as to birds and biodiversity. For further details on the management of the area see Nordstrom et al. (2015).

\subsection{La Faute-sur-Mer (France)}

The town of La Faute-sur-Mer is located on the Atlantic Coast, in the Bay of Biscay, in the Department of Vendée, $20 \mathrm{~km}$ north from La Rochelle (Fig. 1e). It is a small village of about 1000 inhabitants on a narrow strip of land between the Lay river mouth and the ocean. The territory represents a bit less than $7 \mathrm{~km}^{2}$. According to Bertin et al. (2012), the spring tidal range along the coast exceeds $6 \mathrm{~m}$ in the Pertuis Breton and the Pertuis d'Antioche, reaching $4.5 \mathrm{~m}$ to the South and $5.5 \mathrm{~m}$ to the North. The same authors mention that annual-mean significant wave heights are $1.36 \mathrm{~m}$ at Biscarosse (250 km south of La Rochelle), 
$1.81 \mathrm{~m}$ at Yeu and $2.64 \mathrm{~m}$ at Biscay (500 km south). The maximum recorded wave heights are $9.70 \mathrm{~m}, 8.88 \mathrm{~m}$ and $13.9 \mathrm{~m}$ for Biscarosse, Yeu and Biscay respectively. Tourism is the main economic resource of the town and explains the presence of many commercial activities related to this source of income. According to the municipality, up to 35,000 people visit the town on any given day during the summer period. The ecosystems present at the site consist of a natural marsh in the southern part of the territory as well as the beach and dune ridge along the western part of the area.

\section{Methods of analysis}

In this paper we follow the definition of Baart (2013) for a historical storm: the event must be documented reasonably well; its date must be known; and some information on its magnitude must be available. As a definition based on exceedence of thresholds cannot be used, the discriminatory factor is the impact as recorded, and the societal disruption caused at the time of the event. Given this definition, it follows that we cannot go back far in time; the record of impact relies heavily on human occupation of a given area. However, equally, we cannot also get too close to the present because there has been a general tendency towards an increase in exposure in coastal areas, related to the increased occupancy of coastal zones. Finally, the level of coastal protection must also be accounted for, as an event that has occurred recently on a heavily protected coastline would have had a different impact 100 years ago. Thus our analysis of high impact events generally ends after WWII, except at the North Sea and Adriatic Sea sites, where coastal defence raising and strengthening followed the disastrous events of 1953 and 1966 respectively. Nevertheless, for all five coastal sites considered here a comparison between historical events is undertaken, in order to discuss similarities and draw lessons for coastal management practices (Spencer et al., 2015).

Regarding the definition of "historical" event, there are several options available. The first option is a purely "historical" one, basically any event that is recorded in chronicles of some kind, without considering the quality of the report and most importantly the impact that is reported. A difficulty with this approach is the tendency for historical records to report only the largest events, associated with major disruption.

An alternative is to use a physically based definition, based on the exceedence of a threshold of wind speed, wave height and/or tidal water level, without considering either morphological/ecological impact or impact on human beings. Some authors (e.g. Pye and Blott, 2006; Armaroli et al., 2012; Brooks et al., 2012) have instead introduced a combination of absolute physical thresholds and the observed morphological change or damage to infrastructure, classifying also the magnitude of the energy produced over the event, based on the maximum wave height or tidal elevation observed and the duration of the storm. Although this is arguably the most rigorous approach one could adopt, accurate wave measurements only became available after WWII (and in some areas, such as North Norfolk, only in the last two decades), limiting this approach for a period when direct observations are available. There is always the possibility to reconstruct the wave climate during an event with inverse modelling but at the very best this is limited to the 20th century, as reliable wind measurements are required to drive model hindcasting routines.

When it comes to wind, wave and water level records, it is observations of exceptional water levels that are the most commonly available as tidal observations of still water level at some locations have been maintained for hundreds of years. Where these records are not available, or where sites are at some distance from tide gauges, the heights of exceptional water levels can be obtained from levels marked on buildings and/or port and harbour infrastructure. These levels are often referred to in historical reports as "storm surges". Strictly speaking, a storm surge is hydrodynamically defined as the contribution given to an anomalous water level above (and in the case of "negative surges" below) a predicted tidal level by meteorological forcing (the 'inverse barometer' component from atmospheric pressure changes and the much greater effect of wind stress on the sea surface). The water level may be further enhanced by the action of wave processes (wave set-up, wave run-up). However, at the very best for historical records the recorded low pressure is available; thus it is difficult to discriminate in a quantitative manner the tidal from the atmospheric and oceanographic components. Thus, historical analyses like those reported in this paper use the definition of surge as equivalent to the maximum water level recorded for a given storm event.

Coastal flooding is caused by high water levels generated by extreme meteorological events, or 'storms'. These water levels result from the combination in varying proportions of tidal level; surge (which has both wind stress and pressure (the 'inverse barometer' effect) components); and wave activity (which includes water level setup and wave runup at the coast itself). In macro-tidal northern Europe (the sites of North Norfolk and La Faute-sur-Mer in this study) high water levels result from the coincidence of storm-generated surges (with or without additions to total water level from waves) close to, or at, the water levels associated with high spring tides. However, by contrast, on the meso-tidal coast of southern Portugal (Ria Formosa), it is storm-related oceanic waves which play a major role in generating the water level set-up that produces inundation and damage. The same applies to micro-tidal Mediterranean coastlines (Bocca di Magra, Porto Garibaldi), where wave and wind components are the main contributors to total water level.

Reconstructing environmental histories for isolated, sparsely populated and under-developed coastal sites in the past is a challenging task, not least because of the changing paleogeography baselines employed across the centuries. Furthermore, establishing a European record of events is made difficult by the different national and cultural backgrounds that underpin historical records. However, detailed searches can reveal rich documentary resources relating to extreme coastal events, at scales from the individual site to a more regional scale (Garnier, 2015). The research presented here has been largely based on the exploitation of primary sources, consisting of textual archives over the last 350 years. On some occasions we used other sources like paintings, or photographs for more recent events, but textual archives remain overall the most widely available source of information at all study sites.

\subsection{Municipal archives}

A large number of archival sources have been examined through personal visits by the first author to archives. The historical analysis began with the consultation of the documentary information stored in the libraries of the municipality archives of Norwich, Wisbech, King's Lynn, Faro, Comacchio, La Spezia, Ravenna and Venice.

The municipal archives kept in the provincial archives (Norfolk Record Office, Cambridgeshire Archives, provincial archives of La Spezia) allowed us to study the record of the floods in an urban frame, from the examples of the large cities of King's Lynn, Venice and Faro and smaller coastal towns such as Blakeney (UK), La Faute-sur-Mer (France), Tavira (Portugal) or Ameglia (close to Bocca di Magra). Hall or Congregation (assembly) Rolls and books include regular information on climatic extremes. This is because the elected representatives monitored these events in order to take measures (defence of dikes, taking care of victims) quickly when a flood threatened the city or its supply chain. Used in conjunction with the other archives, these numerous city testimonies reveal information about storm surges that affected these urban and rural areas. King's Lynn (and even Blakeney) were large and very important medieval urban centres. During the 14th century, King's Lynn ranked as England's most important port. This makes this site unique for medieval records, similar to the Porto Garibaldi site in Emilia-Romagna with its proximity to the important cathedral town of Comacchio. By comparison, the other Italian (Bocca di Magra), French and Portuguese sites were sparsely occupied before the 19th and 20th century. 


\subsection{State archives}

For the CSS of La Faute-sur-Mer, the registers of the Prefecture and the General Council (Conseil Général) of Vendée contain the most frequent and precise information about storms and their material effects. Most of these technical reports were drafted by public engineers. The archives of the district of Faro (Arquivo Distrital) contain the archives of fishing companies since the 1900s. In particular, the compensations paid to the fishermen victims of meteorological extreme events, such as storms, have been found there. For the CSS of Bocca di Magra, we studied the State Archives of La Spezia (Archivio di Stato della Spezia). The Archive Collections of the Prefecture (Fondo Prefettura) are undoubtedly the most interesting ones because they contain the archives of the company responsible for drainage and irrigation.

\subsection{Archives of private entities}

Kept in the Cambridgeshire Archives (Cambridge), the archives of the Bedford Level Corporation are central to this exercise; for more than 200 years, the Proceedings and Order Book of the Conservators of the Level recorded all the business to do with the management of The Fens (originally a region of periodically flooded fresh- or salt-water wetlands, now low-lying, artificially-drained and flood-protected agricultural land) and of the marine embayment of The Wash. The records of their meetings begin in 1663. Very soon thereafter, both sets of records are full of complaints from owners of flooded lands; and full, too, of references to the rebuilding of broken banks, to the opening of blocked channels, and to the improvement of difficult navigation routes. The series S/B/SP of the archives of Cambridgeshire contains 2314 petitions (although care should be taken in examining these records as they may not be specific to the RISC-KIT case study site which lies to the east of The Wash embayment). Of these, 260 concern problems of sea surges and floods. Drafted by several landowners, who were victims of these extreme events, the petition is often precisely worded. As well as the names and places of residence of the authors, the records usually indicate the date (day and/ or month) of the event, and then provide an exact description of the damage caused by the flood waters. When the damage needed to be repaired, but was too expensive, petitions indicate the monetary figures asked for by the victims and the favourable answer (or not) given by those in charge of the Bedford Level Corporation.

In Liguria, the archives were provided by the Lunense canal company, locally called "Consorzio di irrigazione del Canale Lunense". They cover a period between the end of the 19th century and the 1950s and report natural disasters mainly occurring in the valley of the Magra River. All concern floods, generally flash floods, which destroyed the valley by taking away parts of the dikes and by flooding cultivated land.

\subsection{Books of the scholars}

The Cambridge University Library holds some very rich documentation on this topic. These are mostly books dedicated to a specific locality within the case study site. Their authors were local scholars who tell the story of their parish. Some of the authors were scientists from the 19th or the beginning of the 20th centuries who were interested in this information for geomorphological or meteorological aspects. The information concerning storms and storm surges is consequently random and very localised (e.g. a single village is mentioned) and it is not always easy to affirm that an extreme event reported for a particular village affected the whole case study site coastline. On the North Norfolk coast, the acquisition of large sections of the barrier coastline for nature conservation in the 1910s and 1920s led to the building of small field stations at Blakeney Point (1912) and Scolt Head Island (1924) and these facilities in turn allowed the regular mapping and monitoring of coastal ecological and geomorphological change, including storm impacts.

\subsection{Archives of the navy}

A large part of the historical data collected on the Portuguese and Italian sites comes from the archives of the Portuguese and Italian Navies, kept in the library of the Departamento Marítimo do Sul of Faro and the station of the Servizio dei Fari e del Segnalamento della Marina Militare of Porto Garibaldi respectively. In Faro, the maritime museum "Almirante Ramalho Ortigão" also displays the techniques of fishing and everyday life of the local fishermen in the first half of the 20th century. Reports and books dedicated to the naval activities in the region, as well as collections of old photos regarding housing and coastal landscape, were found, consulted and used.

\subsection{Press}

The local press was also examined because it can be a major source of information, often used for documenting meteorological events (see for example Llasat et al., 2009). Actually, the contents of the documentation grew considerably during the first half of the 20th century thanks to the development of the European democratic model. For the Ria Formosa, several newspapers (Povo Algarvio, O Algarve, Folha de Domingo) published very detailed articles on the cyclone of February, 1941. In Italy we exploited the local newspapers (Gazzetta della Spezia, Giornale di Spezia, La Stampa, Gazzetta Ferrarese, Corriere Padano) from the 1860s onwards. Some of them evoke natural disasters in Bocca di Magra and Porto Garibaldi. The French newspaper L'Ouest-Eclair also published articles on the occasion of storms. These articles evoke the damage suffered at the site of La Faute-sur-Mer. Besides, the indication of the flooded surfaces and of the damaged dikes, these press articles contain photographs taken a few hours after the storm, thus documenting in detail the immediate aftermath.

\subsection{Old charts}

Old numerous maps were found for the last 300 years, in particular military maps of the "Istituto Geografico Militare" and of the French and Portugese Navies, which began to map the coastal zone from the end of the 19th century. The libraries of Ferrara (Biblioteca Ariostea), Ravenna (Biblioteca Classense) and Venice (Biblioteca Nazionale Marciana) have maintained archives on regional flooding since the 17th century and outstanding collections of old maps. Maps of the CSS Porto Garibaldi were also conserved by the Kriegsarchiv (War Archives) of Vienna.

Sometimes published at a very large-scale (1:5000), they describe exactly the housing environment, the plots of land and the nature of the ground, such as the presence of swamps, dunes or woods according to the landscape of the examined site. Consequently, these old maps give a precious perspective on the occupation of the territory of the case study sites and allow a landscape approach towards the coast, its evolution and the geophysical consequences of storms since the 16th century.

The oldest map of Scolt Head Island, North Norfolk coast, is that of Lucas Janssen Waghenaer of Enklingven and dated 1585, then William Faden's map of 1797 (which also covers Blakeney) and then the First Edition of the Ordnance Survey in 1824. The maps are reproduced in Steers (1960). There is a reference to a 1586 map of Blakeney Haven which is reproduced in the 2nd Report of the Tidal Harbours Commission, 1846.

\section{Results: inventory of events}

Events occurred at local and regional scales and are reported in the RISC-KIT Database (see Ciavola et al., this issue). The information below is restricted to the five case study sites. It indicates the observed impacts and quantitative and qualitative socio-economic, cultural and environmental data on each event, where possible. 


\subsection{North Norfolk (UK)}

\subsubsection{5-1953 period}

On 25 November 1665, a storm surge driven by a north-westerly wind removed some of the marsh banks along the North Norfolk coast, and destroyed the wheat which was growing in the marshes. The storm also swept a ship right over the shingle bank from the North Sea into the Salthouse channel, which at that time ran from Salthouse Broad, behind the gravel barrier and out from the River Glaven. This channel disappeared sometime around 1850, blocked by the gradual landward movement of the gravel barrier (Cambridgeshire Archives, KSB/SP 1-2232) and as a result of siltation from the reduction of the tidal prism, itself the result of land reclamation around the villages of Cley and Wiveton (Hooton, 1996).

Twenty-five years later, on 8 October 1690, a north westerly gale associated with a high tide struck Cley. The bank broke and 66 acres (264 ha) of wheat, presumably already winter sown, were covered under 6 feet $(1.8 \mathrm{~m})$ of water. The water reached a depth of 20 feet $(6 \mathrm{~m})$ at Cley quay and several houses, including the George Inn, were under 4 feet (1.2 m) of water (Hooton, 1996).

Between 1735 and 1749, the coast between Wells, Blakeney, Cley and Salthouse was severely hit when it was subjected to four violent storms. A north-westerly storm sprang up on the night of Sunday 15 February 1735 and continued to blow until the following Tuesday morning, when it coincided with a high spring tide. Cley was described as "almost demolished". Nine feet $(2.7 \mathrm{~m})$ of water covered the marshes while the route to King's Lynn was cut off (Gough Manuscript, British Library).

On 7 February 1741, at about 6 a.m., a very high tide flooded all the marshes on both sides of the channel at Cley, breaking down the greater part of the marsh banks, especially the East Bank which was almost wholly destroyed. The flood broke down most of the wall next to the Salthouse road. Witnesses stated that this tide was much greater than that which had occurred in the year 1735 .

Ten months later, on 1 December 1741, a new storm hit the same area. While it was not as severe as the previous one, it flooded Cley marshes but spared the village of Blakeney. In Cley, many houses were flooded and the malt houses were considerably damaged.

Then, in February 1749, a more serious sea flood occurred, but this still was not as severe as that in 1741. All along the coast at Wells, Holkham and Salthouse, the archives describe a similar disaster, with houses flooded.

After a long interval with no major events, the year 1883 was a dramatic year in the locality of Wells, which suffered a major flood, covering the quay and Freeman Street. This occurred on 11 March. Four hundreds acres ( 1600 ha) of land owned by the Norfolk Estuary Company were flooded, as well as many parts of King's Lynn. The water level at the dock reached 29 feet and 11 inches (about $8.7 \mathrm{~m}$ ) while the tide entered St. Margaret's church during the evening service (Hillen, 1907).

Fourteen years later, on 30 November 1897, Wells was again the victim of the sea. An exceptionally high tide flooded part of Freeman Street and also damaged the road leading from the quay to the Point and the Lifeboat House (Purchas, 1965). This storm also breached the north bank at Cley and is recorded at Blakeney Quay with a level of $4.96 \mathrm{~m}$ ODN (Steers et al., 1979).

After 1900, the area continued to be affected by North Sea floods For example, high water levels were recorded on 26 August 1912, 12 February 1938, 8 January 1949 and 1 March 1949. These floods had minor impacts on the RISC-KIT case study area, although their impacts further around the coast were sometimes more severe (e.g. the 1938 flood caused major devastation at Horsey, $60 \mathrm{~km}$ to the east of the RISCKIT case study site). The second storm of 1949 flooded houses and roads in and around Salthouse.

\subsubsection{The 1953 North Sea storm}

The storm surge of 31 January - 1 February 1953 showed the characteristics of a SE tracking surge. With this type of storm, the clockwise rotation of the deep cyclone around an anticyclone (west of Ireland) strengthens the pressure gradients on the right hand side of the depression, giving high wind speeds over the western North Sea (Muir Wood et al., 2005). The winds are then directed southward with their persistence being determined by the rate of movement of the low-pressure system. Wolf and Flather (2005) have argued that the 1953 surge was exceptional as a result of the northerly gales (up to hurricane force (Steers, 1953)) west of the storm centre, the track of the depression along the axis of the North Sea bringing the gales to bear on the shallow waters of the western and southern margins of the basin, and the slow speed with which the storm moved away, increasing the duration of the northerly gales. Weather records from the Dowsing Light Vessel $\left(53^{\circ} 35^{\prime} \mathrm{N}, 0^{\circ} 55^{\prime} \mathrm{E}\right)$ show that wind speeds $>20 \mathrm{~m} \mathrm{~s}^{-1}$ (Beaufort Force 9 , strong gale) were maintained for a $24 \mathrm{~h}$ period during the passage of the storm, generating a surge $>2.25 \mathrm{~m}$ and, at a conservative estimate, a significant wave height of $7.8 \mathrm{~m}$ just off the Norfolk coast (Wolf and Flather, 2005). The most widespread effect of the storm surge was the flooding of all the reclaimed marshes; thus, for example, 1.5 square miles (388 ha) of farmland west of Wells were inundated (Grove, 1953). The sea walls were overtopped, and breaches formed in most cases from the rear, as in the case of the great bank running from Wells Quay to the harbour mouth. On Scolt Head Island, the seaward foot of the high dunes near The Hut was cut back 8-10 yards (7-9 m) and a 'breakthrough' was created through an area of low dunes towards the eastern end of the island. At Far Point, Blakeney, the spit was driven inland 30-40 yards (27-37 m) with some loss of low dunes and channelling through the dunes. The gravel barrier between Cley and Weybourne was breached at Salthouse with a gap 30 yards $(27 \mathrm{~m})$ wide (Steers, 1953). There was extensive flooding of buildings, disruption of power, water supply and roads, and damage to properties in Wells, Blakeney, Cley and Salthouse. In Wells, the station and train line were also flooded. At Holkham Station, the railway embankment was washed away, and the line from Hunstanton and Burnham Market to Wells (including the stretch past Holkham) never reopened following the surge (Baxter, 2005). Three lives were lost in Cley. The water levels recorded in 1953 (5.65 m ODN at King's Lynn; $5.13 \mathrm{~m}$ ODN at Wells Quay; $6.07 \mathrm{~m}$ ODN at Blakeney Quay (Steers et al., 1979)) were not seen again until 1978 (5.92 m; $4.91 \mathrm{~m}$; $4.90 \mathrm{~m}$ (Steers et al., 1979)) and 2013 (6.05 m; $5.31 \mathrm{~m} ; 6.30 \mathrm{~m}$ (Spencer et al., 2015)).

\subsection{Ria Formosa (Portugal)}

\subsection{1. $1816-1860$ period}

The available historical material provided a list of 13 coastal/marine major storms from the beginning of the 19th century. For the previous centuries, historical information is scarce because the barrier islands were uninhabited.

Between 1816 and 1860, the region was hit by 4 severe storms. It is likely that there were smaller storms in that period too but, having smaller energy, no signs of these events were found in historical documents. That of the 1816 is described in archives as a very violent storm associated with very powerful waves which struck the coast at Tavira. The wind sank two fishing ships, ripped the roofs of numerous houses and uprooted trees. On the coast, the huts of the local fishing communities were totally destroyed. These descriptions of damage correspond approximately to a wind with strength 10 on the Beaufort scale.

On 1 January 1840, another severe storm is retained in the local memory as shown by a religious painting of the hermitage of São Lazaro (also known as Nossa Senhora do Livramento) located in Tavira which shows a fishing boat submerged by waves. The storm caused important damage at Tavira and on the nearby islands. Fishermen's huts were taken by the sea and numerous roofs were torn away.

On 2 November 1853, Olhão and the nearby islands were destroyed by a storm and archives describe a "horrible storm" with waves striking houses and causing the collapse of the stone walls of the Olhão quays.

On 19 November 1860, a new disaster occurred and archives actually 
evoke a cyclone to have occurred. It lasted $2 \mathrm{~h}$ and caused very important damage to the built environment of the entire region of Faro and on all the islands.

Ria Formosa then experienced a long period free from high intensity storms for almost a century. This long period of relative calm ended in 1941 when the entire Iberian Peninsula faced one of the largest natural disasters of the last 200 years.

\subsubsection{The "cyclone" of 15 February, 1941}

On 15 February 1941, reports from the navy indicated that since the morning the coast had been hit by a violent wind coming from the southwest, associated with a deluge, accompanied by downpours and hail, which destroyed the inland fields of broad beans and wheat in the Algarve.

A barometric pressure of $948.29 \mathrm{hPa}$ was recorded by the meteorological services on 15 February, the lowest pressure recorded in the Algarve since 1854. The wind speed was estimated at $127 \mathrm{~km} / \mathrm{h}$ $(35.28 \mathrm{~m} / \mathrm{s})$, equivalent to a wind force of 12 on the Beaufort scale. Thousands of trees were uprooted. Zinc plate roofs were lifted as paper sheets while eucalyptus and pines were uprooted and thrown on the ground. More importantly, it is mentioned that the sudden rise in the water level covered a large part of the islands and flooded the 'armações', the buildings where the tuna fishing nets were kept. The village of Cabo de Santa Maria (a tuna fishing camp) on Barreta Island was totally destroyed. At Ancão Peninsula a new inlet was opened. The same storm destroyed the "armação" of Medo das Cascas close to Tavira, one of the most important in the region (Santos et al., 1989).

Within the eastern part of the system, the opening of an inlet almost $1000 \mathrm{~m}$ wide (Cochicho Inlet, former Cabanas Inlet) provoked the destruction of Cabanas Island (Freitas and Dias, 2013). This significant change in island morphology triggered the subsequent sedimentation and closure of the Tavira artificial inlet (opened in 1927) and the disappearance of the internal canal that ran parallel to the island (Freitas and Dias, 2013), which had impacts on the socio-economic fabric of the area. Despite such large geomorphological changes on the islands and the disappearance of three fishing camps, there were no casualties, only material damage.

Archives evoke "gigantic" waves which impacted the peninsula of Ancão and threatened 130 people. On the island of Culatra, dozens of fishermen's houses disappeared. The sailors lost their boats, taken by the sea, as well as their fishing equipment. A mill was destroyed and the southern part of the cannery at Balsense collapsed. On the island of Tavira, the sea destroyed the largest part of the huts which were taken by the current. In Faro, the wind destroyed the houses of the Guarda Republicana in the Avenida da República. Everywhere, in Faro and in the countryside, street lamps, telegraph and electric poles were destroyed, preventing communications between the province and the capital. The losses were catastrophic for the fishing and merchant fleets. In the afternoon of 17 February, the ship "Maria Joana" was wrecked because of the storm near Faro. A tanker of the transport company of Guadiana disappeared during the cyclone. Other boats transporting sugar and coffee sank. Sometimes boats crossed over dikes and quays, becoming beached 100-200 $\mathrm{m}$ inland. The social and economic consequences of the storm were very significant and seriously damaged the resilience capacity of the inhabitants. For example, the authorities inoculated, as a matter of urgency, the inhabitants of the islands after the storm to prevent an outbreak of smallpox. More than 100 people (women, children, men) were affected by the disaster on what is called currently the beach of Faro (Praia de Faro). In Fuzeta, part of the residential area was invaded by the sea. Hundreds of houses were flooded and boats suffered severe consequences. The fishermen lost almost all their equipment for fishing octopus, one of the main income sources in the area. Consequently, unemployment increased and scarcities of goods and services affected many families. The storm had an important effect on the regional economy of the Algarve, with damage costs of around 150,000 euros (Muir Wood, 2011), equivalent to 15 million euros at current prices.

\subsection{Bocca di Magra (Italy)}

Only six historical storms were extracted from the historic documentation between the 17th and the mid-20th century for the region of Liguria. The first storm occurred on the 11 November 1613 and struck, according to historical sources, the whole of Liguria but in particular the city of Genoa. The engraving of the German artist Joseph Furttenbach describes a very impressive " mareggiata " (sea storm in Italian) in the harbour (Newes Itinerarium Italiae, 1627). Probably exaggerated, the engraving shows waves of several meters, which cause the wreck of caravels and galleys lying within the harbour. To the right and at the bottom of the scene, the sea breaks the dike and takes people. On the 17 January 1636, a severe wintery storm is indicated in Liguria.

The next storm occurs much later because it is mentioned in the documentation as being from 18 December 1886. For the first time, the event concerns an area close to Bocca di Magra, the RISC-KIT case study site. More exactly, it involved a violent windstorm associated with high waves, which submerged the Ligurian coast and sank a ship coming from Sardinia. At Lerici, waves breached a part of the dike and submerged riprapwalls, so that a part of the city was flooded. A further storm ravaged the Ligurian coast on the 27 November 1898. Dozens of ships were sunk or grounded further inland from the coastline because of the strength of the waves. In Genoa, the sea caused a $24 \mathrm{~m}$ breach in the Lucedio dike, one of the main ones of the port.

The first example of a storm directly affecting the site of Bocca di Magra is mentioned in the newspaper Gazzetta della Spezia. It occurred during the night of 20 October 1901 and the press article of the 26 October 1901 seems to indicate that it did not impact the rest of Liguria. The Mistral, a cold dry north or northwest wind, which blows down through the Rhone Valley to the Mediterranean Sea, played a major role in the disaster. The alert was given at 3 a.m. by the semaphore of Monte Marcello and at 6 a.m. the authorities of La Spezia were informed about the storm and its catastrophic effects. More exactly, 38 boats called "Navelli" and "Tartanes", which were being used to transport marble from inland quarries, were taken out to sea while others were grounded on the river banks at Bocca di Magra. An expert evaluation made by the Secretary of the Treasury of Castelnuovo Magra $(7 \mathrm{~km}$ to the northeast of Bocca di Magra) estimated that the losses amounted to 150,000 Liras (value of 1901; approximately 670,000 euros at current prices).

Finally, Bocca di Magra experienced a violent storm on the 19 February 1955 which is well reported in archives and press reports. Meteorological Office records specify wind speeds in excess of $100 \mathrm{~km} / \mathrm{h}$ and that the pressure reached as low as $987.5 \mathrm{hPa}$. Waves with maximum heights from 10 to $13 \mathrm{~m}$ were estimated and there was damage to the dikes in Genoa (Gallino et al., 2011).

\subsection{Porto Garibaldi (Italy)}

Fifteen major events occurring between 1562 and 1927 have been identified in the regional archives. Seven floods and two storms hit the territory of Comacchio and Magnavacca with six events including both riverine and marine flood influences.

\subsection{1. $1550-1870$}

Records show periods with a relative high frequency of extreme events alongside other periods with few, if any, events. The period between 1550 and 1650 includes only one event: a flood in 1562. This lack of extreme events can be explained by two reasons. The first possibility is that gaps exist in the documentation. This seems unlikely because other municipal records do not contain gaps during this hundred year period. Therefore, if a disaster occurred, one can be confident that it would have been recorded in the municipal archives. The second, more likely, possibility is landscape and climatic changes. The years $1550-1650$ represent the peak of the Little Ice Age, a colder episode thought to have limited rainfall and decreased storm activity in the Adriatic Sea. This hypothesis is supported by the work of the historian Dario Camuffo 
(Camuffo et al., 2000) which shows a decrease in sea surge frequency in the Adriatic Sea from the middle of the 16th century to the 1650s.

A second period of moderate frequency (six events) can be observed between 1650 and the 1730s. Climatically, the period is marked by a relative lull in the Little Ice Age and a higher frequency of climate extremes. Once again, the work of Camuffo et al. (2000) confirms this observation. Four floods (1652, 1677, 1681 and 1705) and three storms (1672, 1705 and 1737) affected the case study area.

A clear peak in the occurrence of events can be observed between the 1840s and 1870. During this 30 year long period, seven extremes are recorded of which four were marine storms.

\subsubsection{The "mareggiata" of 22 February 1927}

The catastrophe of 1927 is well documented in local newspapers and in the literature of the time. Indeed, weather stations already existed in the northern Adriatic Sea (Venice, Ferrara, Bologna, Rimini). Historical sources talk about a meteorological episode which was extremely severe throughout Italy. Heavy rain and snowmelt in the Apennines affected the entire Emilia-Romagna region. The atmospheric pressure was not particularly low (the state's Hydrological Annals (Annali Idrologici 1927) registered in Venice a barometric pressure of $1002 \mathrm{hPa}$ ) although typical of low-pressure weather systems in the Adriatic (Trigo and Davies, 2002). In the storm catalogue of Camuffo et al. (2000), the 1927 event is one of the highest "Acqua Alta" (storm surges in Italian) ever recorded in Venice since the year $782 \mathrm{AD}$. In Porto Garibaldi, meteorological reports stated that because of the heavy rain and a powerful "Tramontana" (a northeasterly or northerly winter wind that blows from the Alps and Apennines), the onshore coastal current met the powerful outflow of the harbour channel (Gazzetta Ferrarese newspaper, 22/02/1927). This combination of flows produced flooding from both the river and the Adriatic Sea. Floods did not spare the neighbouring towns. Rimini was hit by the overflow of the rivers Ausa (which at the time was flowing through the town) and Marecchia, while water flooded the streets of Comacchio.

Damage caused by the storm should be evaluated with caution because of fascist propaganda (Benito Mussolini government) that took advantage of the disaster to promote the government's action. However, the technical contents of the local reports and newspapers give a reliable idea of the losses and costs. On-site, the sea water of the canal flooded the docks' channel while powerful waves destroyed most of the breakwaters at the entrance.

The beach of Porto Garibaldi, located on the northern side of the harbour, suffered strong erosion and other beaches nearby were also damaged. Dunes were severely eroded as well. The restaurants and Bagni (private beaches and facilities) "Apollo", "Esperia" and "Nettuno" were totally demolished by waves.

The line of houses behind the beach was struck by the sea and a report states that certain houses "seem to have exploded" as some witnesses dared a comparison with the explosion of grenades. The coastal road was cut and Porto Garibaldi remained almost isolated from the rest of the region. Financially, the balance sheet was very heavy for the time as the authorities estimated it to be 1,000,000 Liras at 1927 values (approximately 836,000 euros at current prices). However, no source mentions any deaths among the local population.

\subsubsection{Event of 4 November 1966}

The storm was particularly critical for the Emilia-Romagna coastline and caused extensive erosion and flooding due to marine water ingression and river overflow from persistent heavy rainfall. The event was characterised by very high water levels. In Venice the highest level ever observed was recorded at $1.94 \mathrm{~m}$ above height datum; in Goro, at the boundary between the Veneto Region and the municipality of Ferrara, the recorded water level was $1.20 \mathrm{~m}$ MSL. Wave heights ranged around 6-7 m offshore (estimated wave height, gauging stations not present at that time). The high surge level was caused by persistent and strong wind from the south-east (locally named Scirocco). According to numerical reanalysis of the event carried out by the De Zolt et al. (2006), it seems that the high water level observed in Venice was equivalent to a return period of about 250 years.

The whole coastline suffered from erosion and inundation, especially in the province of Rimini (southernmost province in Emilia-Romagna). The Po river delta area, in the Veneto Region, was inundated and agricultural activities were deeply affected by the event. Most farmers and their families moved away from the area, leaving their land abandoned, to find work at industrial sites in other regions (Piemonte and Lombardia). The population decreased from 14,000 to 11,000 people (Perini et al., 2011).

Considering the whole coastline of the Ferrara municipality, between Goro and Lido di Spina, a total of 8600 ha of land were flooded. Porto Garibaldi was inundated by both marine water and fresh water through the navigational channel of Porto Garibaldi itself. The flooding caused damage to structures and particularly to the main coastal road (the SS Romea). During the storm the Fire Brigade, Police and local residents carried out several urgent interventions. At Goro, sand bags were placed along the retaining wall that separates the port itself from other buildings, to reduce the water inflow. Almost 80 families were moved away from their homes. After the storm, in 1968, a $16 \mathrm{~km}$-long earth embankment was constructed between Goro and Porto Garibaldi named the "difesa Acciaioli". The embankment at $+3 \mathrm{~m}$ above Mean Sea Level was placed at varying distances from the shoreline, ranging from $0.5 \mathrm{~km}$ to $1.5 \mathrm{~km}$. Its width was between $7 \mathrm{~m}$ and $9 \mathrm{~m}$ and its eastern side (facing the sea) was covered with bitumen.

\subsection{La Faute-sur-Mer (France)}

On 9 December 1711, over almost 9 h, Vendée and CharenteMaritime were struck by a powerful storm surge which occurred in association with a $5.20 \mathrm{~m}$ predicted high tide in La Rochelle. The tide reached $6.34 \mathrm{~m}$ above tidal datum in the morning. Considerable damage was reported in the region. Archives report the destruction of numerous seawalls and the flooding of saltworks which were vital for the local economy. The authorities of the time estimated the cost of the disaster at 1.19 million euros (current prices) because it took several years to reconstruct the damaged seawalls.

The storm of 21 February 1788 was probably one of the most violent storms in the maritime history of the region (Garnier and Surville, 2011). It was caused by a south-westerly storm winds during the full moon (spring tides), which gave a tidal height of $5.70 \mathrm{~m}$ at La Rochelle. The storm submerged the coast in several places. The barometric pressure recorded at La Rochelle was $976.4 \mathrm{hPa}$ in the afternoon. Several districts of the city close to the port were flooded by the sea. The floods also affected islands (Oléron, Ré) and the town of Les Sables d'Olonne. Almost everywhere, seawalls were breached.

The storm of 1 January 1877 was associated with a $5.60 \mathrm{~m}$ high spring tide in La Rochelle on the evening of 31 December 1876. It was recorded in the registers of the Conseil Général de Vendée and in the archives of the city of l'Aiguillon-sur-Mer. It most probably affected La Faute-sur-Mer (Archives départementales de Vendée, 1 O 799). Again, historical evidence of impact is lacking for La Faute and archives describe only the damage caused in the municipality of La Tranche-sur-Mer. Probably because La Faute was still largely uninhabited, the authorities preferred to describe the flood-induced damages in the closest municipality: l'Aiguillon-sur-Mer, just on the other side of the Lay River.

The first storm tide that led to flooding mentioned in the archives for La Faute-sur-Mer occurred on 27 October 1882. During high spring tides (5.90 m high tide level in La Rochelle), the marshes were submerged by the sea from the Pointe d'Arçay to the hamlet of La Faute and the Port Puaut (Archives départementales de Vendée, $1 \mathrm{M}$ ). Archives report 44.4 ha flooded and $40 \mathrm{~m}$ of seawall breached.

The storm-tide of the 23-24 March 1928 led to a major disaster for the village of La Faute-sur-Mer, as reported by the media at the time (Archives départementales de Vendée 4 S Supp). The available instrumental datasets are numerous. The wind was from southwest and the 
tidal level was almost $6.30 \mathrm{~m}$ in La Rochelle. Collapses occurred on the left sand bank (l'Aiguillon-sur-Mer) of the Lay River. Sources do not report evacuation of the population. The village of La Faute-sur-Mer was separated from higher ground inland. The threat was so great that more than 450 inhabitants of the nearby municipalities (l'Aiguillon, Grues, Saint-Denis-du-Payré) were mobilized to check the seawall at Fenouillet, which protected 7000 ha of farmland. At this locality, archives and press stated that the sea excavated a channel in the dune, opening a $200 \mathrm{~m}$ wide breach which allowed inland flooding. A second breach was opened and waters threaten the farm of "La Violette". The result was heavy damage. The sea flooded more than 120 ha of farmland and cut the road between La Faute and La Tranche-sur-Mer for a distance of $1.5 \mathrm{~km}$. Dunes collapsed and almost disappeared and pines planted by the forestry commission were uprooted and taken by waves.

The second event known to have occurred at La Faute-sur-Mer was the storm of the 13 March 1937 which caused only limited damage. Indeed, the storm hit all of the French Atlantic Coast (from Brittany to the Spanish border) and caused very great damage elsewhere. The event corresponded to a violent storm in phase with a large spring tide $(5.80 \mathrm{~m}$ tidal height in La Rochelle). In La Faute-sur-Mer, a seawall was breached over a distance of $20 \mathrm{~m}$ but this damage was quickly repaired, thanks to the help of soldiers and inhabitants. These urgent measures limited the flood to the low fields situated behind the seawall (Archives départementales de Vendée, 18 S Supp).

Only a few years later, La Faute-sur-Mer was again victim of a storm on 16 February 1941 (Archives départementales de Vendée H-). SouthWest winds and a tidal level of $5.30 \mathrm{~m}$ in La Rochelle flooded the polders of the right bank of the River Lay, upstream from the bridge of l'Aiguillon. Performing a historical numerical hindcast of the storm surge associated with this storm, Breilh et al. (2014) revealed that this storm had a track and produced wind fields and waves very similar to those of storm Xynthia (February 2010). Combining historical water levels and numerical measurements, these authors also stated that the storm surge exceeded $1.5 \mathrm{~m}$ in La Rochelle, although the maximum water level was probably slightly lower than during storm Xynthia. The road between La Faute and La Tranche-sur-Mer was submerged by $0.60 \mathrm{~m}$ of water and the River Lay overflowed. Strong erosion was also observed in the right seawall of the River Lay and it was also necessary to remove the sand accumulated against the dike for $2 \mathrm{~m}$ in height.

During the night of 14-15 February 1957, a severe storm coming from the North-West occurred in the central part of the Bay of Biscay, with wind gusts reaching $40 \mathrm{~m} / \mathrm{s}$. The lowest pressure and strongest winds were recorded to the North of Oléron Island with $988 \mathrm{hPa}$ and an average wind speed of $28 \mathrm{~m} / \mathrm{s}$ from the west, respectively. Although this storm induced a moderate surge of the order of $1 \mathrm{~m}$ according to Breilh et al. (2014), the surge peaked at the same time as the highest astronomical tidal level (about $6.0 \mathrm{~m}$ in La Rochelle). The marshes of the Marais Poitevin bordering the Aiguillon Cove were particularly affected by flooding and it was even reported that "the sea gained in $15 \mathrm{~min}$ the area it lost in seven centuries" (Breilh et al., 2014). To the west of La Faute-sur-Mer, this storm produced a significant erosion of the dunes over several hundred meters of the shoreface. The dikes breached at many locations along the river Lay and induced significant flooding in the nearby municipality of l'Aiguillon. However, damages were very limited in La Faute-sur- Mer (Sud-Ouest Newspaper, 1957).

The storm Xynthia (February 2010) occurred at night and the water passing over the dikes flooded the town when people where sleeping. It resulted in the death of 27 persons, mainly by hypothermia or drowning as they were trapped in their houses. Some people had to break the ceiling to evacuate from their house (Vinet et al., 2012).

\section{Historical analysis: storm recurrence and intensity}

In terms of variability, the number of storms with reported major damages at the different CSS reveals large disparities between sites and over time (Table 1). Certain centuries are represented by very few storms.
Generally, the 17th and 18th centuries display a reduced number of events. This lack of extreme events can be explained in two ways: by climatic variability and/or by gaps in documentation. Furthermore, for sites where the level of occupation was low it may well be that only some events were reported. However, the North Norfolk CSS is well documented, with records of floods and their impacts available over several hundred years, and here the situation is quite different from the other case study sites. The site corresponds to a region that was formerly of strategic importance to the English Crown against Spanish, Dutch and French threats and where there were extensive trading networks with mainland Europe and Scandinavia. As a consequence, much archival material is available relating to historic storms in this region. Here the century with the greatest number of extreme events is, unlike the other case study sites, the 18 th century.

On the other hand, the Portuguese, Adriatic and French case studies are much more complex because they mostly remained uninhabited till the beginning of the 20th century. In the early 1900s, the population at all these sites was very limited, consisting of small fishing communities located mainly on islands, peninsulas and at the coastline. For this reason, it is very hard to find historical documents and consequently data about sea surges or wave storms that affected these settlements as they did not exist at the time.

A search of trends based on instrumental data and recorded impacts occurring mainly in the 19th and 20th century was attempted by the MICORE project and is summarized by Ciavola et al. (2011) and Ciavola and Jiménez, (2013). They generally found variable changes in storminess for the areas represented by the case studies. For the French Atlantic coast they found an increase in storm intensity and frequency over the period 1958-2008. In the northern Adriatic over the period 1960-2008 they found an increase in surge heights. For the south coast of Portugal over the period 1958-2008 they actually found a decreasing trend in the magnitude of storm waves, no trend was found in surges. The Western Italian coast and the North Sea coast of the UK were not studied, so no information for the Bocca di Magra and North Norfolk sites are available.

The use of long historical records may allow scientists to estimate the real frequency of storms over a centennial sample and the presence of cycles induced by large scale-circulation phenomena. For example, Camuffo et al. (2000), using written historical records from $840 \mathrm{AD}$ to the current century, were able to exclude the presence of teleconnections between the El Niño-Southern Oscillation (ENSO) and surges flooding Venice or Western Mediterranean storms. Likewise they excluded teleconnections between Venice surges and the Northern Atlantic Oscillation (NAO). The absence of historical instrumental records can be overcome using reanalysis like ERA-40 (Uppala et al., 2005) but the uncertainty in large and long-term model hindcasting when drawing conclusions on storminess trends should be taken into account.

Table 2 presents the frequency of historical storms causing severe damage at each of the study sites. The frequency is calculated dividing the observation period over the number of events. It is important to consider the values indicated in the table as a qualitative estimation and not as absolute values. Moreover the variable degree of occupation of the same region over the centuries makes comparisons through time difficult.

\section{Discussion}

\subsection{The historical construction of the concept of coastal vulnerability}

In order to properly understand how European coastlines have developed in the context where vulnerability has increased over time, we believe it is necessary to consider historical changes that European societies have undergone since 1700 .

\subsubsection{The time of the precautionary principle (1700-1900)}

Historically, for continental populations and elites, coastal areas and the ocean were often perceived as hostile. Their inhabitants had very bad reputations. They were shown to be "wreckers", i.e. to mislead ships by 
Table 1

Number of historical storm events with major damages in the analysed case study sites between 1600 and 2000 . These are compared also with similar events that occurred between 2000 and 2016

\begin{tabular}{lllllll}
\hline Century & 17th & 18th & 19th & 20th & 2000-2016 & Total \\
\hline North Norfolk & 2 & 4 & 2 & 3 & 1 & 12 \\
Ria Formosa & & & 4 & 4 & 3 & 11 \\
Liguria & 2 & & 2 & 6 & 10 & 20 \\
Porto Garibaldi & 1 & 2 & 4 & 3 & 1 & 11 \\
La Faute-sur-Mer & & 2 & 2 & 4 & 1 & 9 \\
Total & 5 & 8 & 14 & 20 & 16 & 63 \\
\hline
\end{tabular}

lighting fires on the beaches to cause their shipwreck and then to plunder them, having massacred their crews.

European Monarchies were interested in coastal areas only from a strategic perspective because the coasts were exposed to the risk of invasion from their neighbours (French, Spanish and British) until the 1850s. Under these conditions, the coast was regarded as an uninhabited and wild area. Nevertheless, from the 17th century, because of the new naval ambitions of European monarchies, coastal space was locally militarized with fortifications and military harbours (Cozens-Hardy, 1938; Albone at al, 2007).

For resident coastal populations, however, the perception of their environment was completely different. The sea and its margins was first and foremost a nourishing space, exploited in a sustainable way and according to a requirement impossible to circumvent: its security. The foreshore was an extension of the villagers' landholdings and conflicts of use between neighbouring communities were frequent. Indeed, many stakeholders converged in this zone of contact between the land and the sea.

For those concerned with development, the militarization of the coastline by the monarchy resulted in an early cartography which makes it possible to form a very precise idea of these old littoral landscapes. Thus, for example in Fig. 2a, the littoral dunes are represented in detail, as a series of massive dunes bounding a coastal wetland. The only visible traces of human impact in this dune area are the forts and the many saltworks. The villages and hamlets are settled on lands located above sea level; the natural coastal protection against river floods and sea surges provided by the dunes and wetlands is clear (Garnier, 2015). The comparison with Fig. $2 b$ that shows the present configuration of the site clearly reveals the human impact on the coast (urbanization, beach occupation for tourism, swamps reclamation, construction of artificial channels, etc). It is also worth noting the vital role of the lagoon of Venice. The Venetian lagoon's network of channels crossing tidal flats and marshes were too deep for marching armies but too shallow for attack by ships, being the best protection of the city against invasion, making the "Serenissima Republic" one of the Mediterranean economic and military powers for centuries.

\subsubsection{The choice to live and work close to the sea (1880s-2016)}

From the 1880s, a new perception of European coastlines supported a new urbanization closer to the sea. With the rise of steam ships equipped with iron hulls, ports start to increase in presence and size, strongly modifying coastlines with the creation of vast basins, warehouses and quays. This fundamental economic transfer was accompanied by a new social interest in the coast. This recreational use stemmed from the

Table 2

Frequency (in years) of storms causing severe damages in the case study sites between 1600 and 2016.

\begin{tabular}{lllll}
\hline & 17th & 18 th & 19 th & 20 th \\
\hline North Norfolk & 50 & 25 & 50 & 33 \\
Ria Formosa & & & 25 & 25 \\
Liguria & 50 & 50 & 50 & 17 \\
Porto Garibaldi & 100 & 25 & 33 \\
La Faute-sur-Mer & & 50 & 50 & 25 \\
\hline
\end{tabular}

promotion of the therapeutic benefits of the sea and the attractiveness of coastal climates and landscapes to painters and writers.

The process of transformation of European coasts accelerated from the 1920s and coastlines underwent modifications much more dramatic until the Second World War, in particular because of the construction of the German Atlantic wall in the case of the French Atlantic coast. New coastal roads were built close to the shore with railway lines cutting through dune systems. The railway thus became a barrier, worsening the impact of floods by creating new basins and by disturbing drainage networks. These new transport routes served new nodes of urbanization of villas and allotments by the sea. The new inhabitants were completely naïve as regards littoral risk. Added to these residents were increasingly large numbers of tourists in the summer period. They required easy access to the beaches. Everywhere passages were opened in the dunes, with the widespread trampling of the native vegetation (Fig. 3). Cromer, to the east of the North Norfolk case study site, became a resort town in the early 19th century. The golf courses at Hunstanton and at Brancaster were founded in 1891 and 1892 respectively (the latter with royal patronage, as the 'Royal West Norfolk Golf Club', from the then Prince of Wales (later King Edward VII)). Rimini, in the same region as the CSS of Porto Garibaldi, had the first beach establishment opened in 1843. The Porto Garibaldi area completely changed, becoming a coastal resort (compare Fig. 2a with Fig. 2b).

All the factors listed here contributed to a higher degree of exposure of the coastline to the impact of high energy events, as the exposure of people and assets increased. The first impact of storms were recorded in a tangible way, through monetary loss of goods or indirect losses for the activities carried out on the beach. These impacts were wrongly perceived as an effect of climatic variability while at the same time the development continued. In the post WWII period, this inexorable process continued at a higher pace, particularly after 1960, planting the roots of contemporary coastal vulnerability. A recent social study by Costas et al. (2015), focussed on the Faro Beach (Ria Formosa) in Portugal, found that residents who choose the location as their first residence voluntarily accept the need to live with coastal risk in exchange for a series of related benefits that they believe to largely exceed expected personal damages.

Emblematic for this process of urbanization and its corollary, the artificialisation of the coast, is the location of La Faute-sur-Mer, Atlantic coast of France. The current site of La Faute corresponds to a narrow sandy territory. The underlying sand shoal dates from the 17th century, a product of the stormy coastal climate of the Little Ice Age. Around 1760, the site was still occupied by the river while slowly the dune ridges were growing (Archives départementales de Vendée, 24 Fi). In 1829, a hamlet was created by some farmers and by 1889 had a population of approximately 150 inhabitants. However, it was only in 1953 that the municipality was created. The only locality of economic importance at this time was the city of L'Aiguillon-sur-Mer, lying behind the strip of land that was to become La Faute and the dune ridge bordering the east shore of the River Lay. From the 1970s, the territory urbanized gradually with the rise of tourist activities. Everywhere, constructions multiplied around the historic hamlet, in particular with the creation of new allotments. The present population of La Faute-sur-Mer comprises 916 inhabitants, of which $46 \%$ are pensioners. In summer, the population of La Faute-surMer can reach 20,000 inhabitants and $98 \%$ of houses are residential buildings (Garnier, 2017).

The Xynthia event highlighted the mistakes that had been made with poorly controlled town planning. About 3000 houses were built on old marshland, including one major area that was below sea level. While not clearly considering the risks, the developers made these sectors less resilient because they did not take into consideration the danger of sea surge and coastal erosion.

\subsection{Building a culture of risk}

\subsubsection{Scientist level}

The historical analysis considered in this paper encompasses a time 

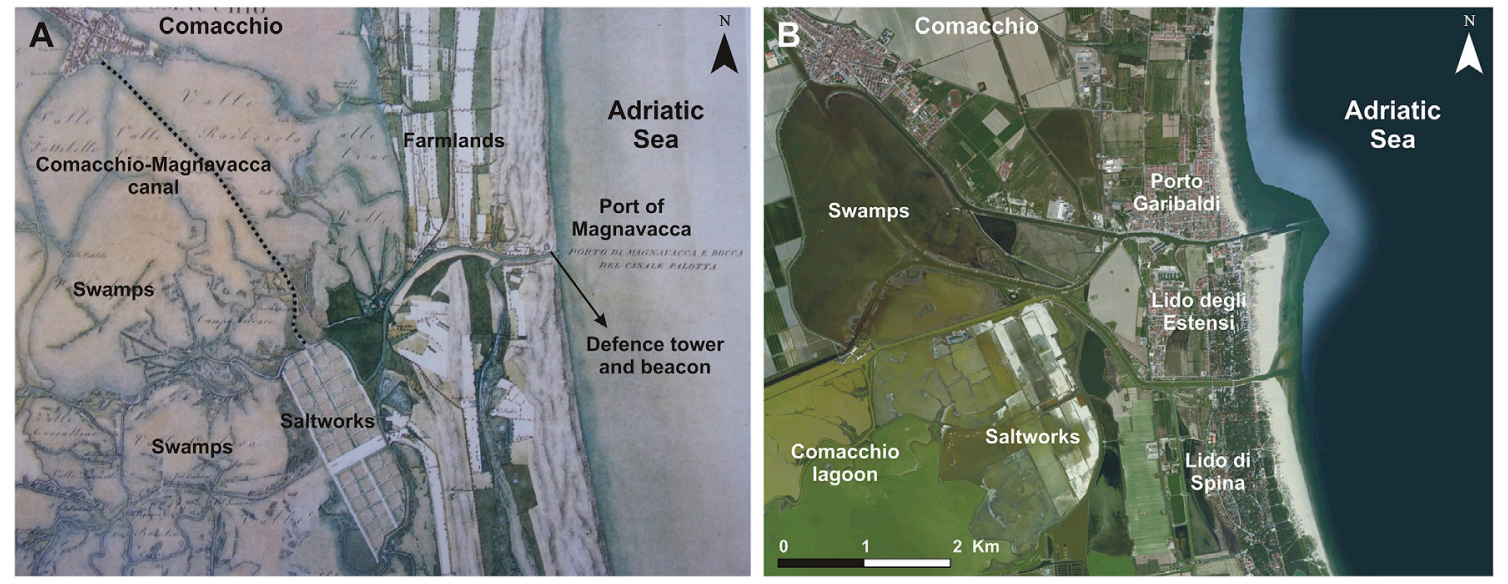

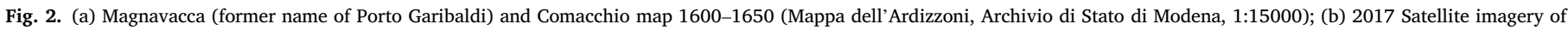
the site.

span for the frequency of storms that at some sites extends back over 300 years. Although the sources of the record of impacts may be qualitative in terms of the physical forcing data (e.g. wave and tide records do not extend beyond the 20th century in most cases), impact data can be considered reliable because these events normally generated large impacts, influencing societal changes, such as large population migrations or changes in land-use. The use of long historical records may allow scientists to better define the occurrence and recurrence of storms over a centennial sample. From an engineering viewpoint, the concept of the probability of occurrence (e.g. the return period) is based on a data series frequency analysis, often limited to datasets of 30 years or less, being the obtained geometric distribution often extended to allow for changing

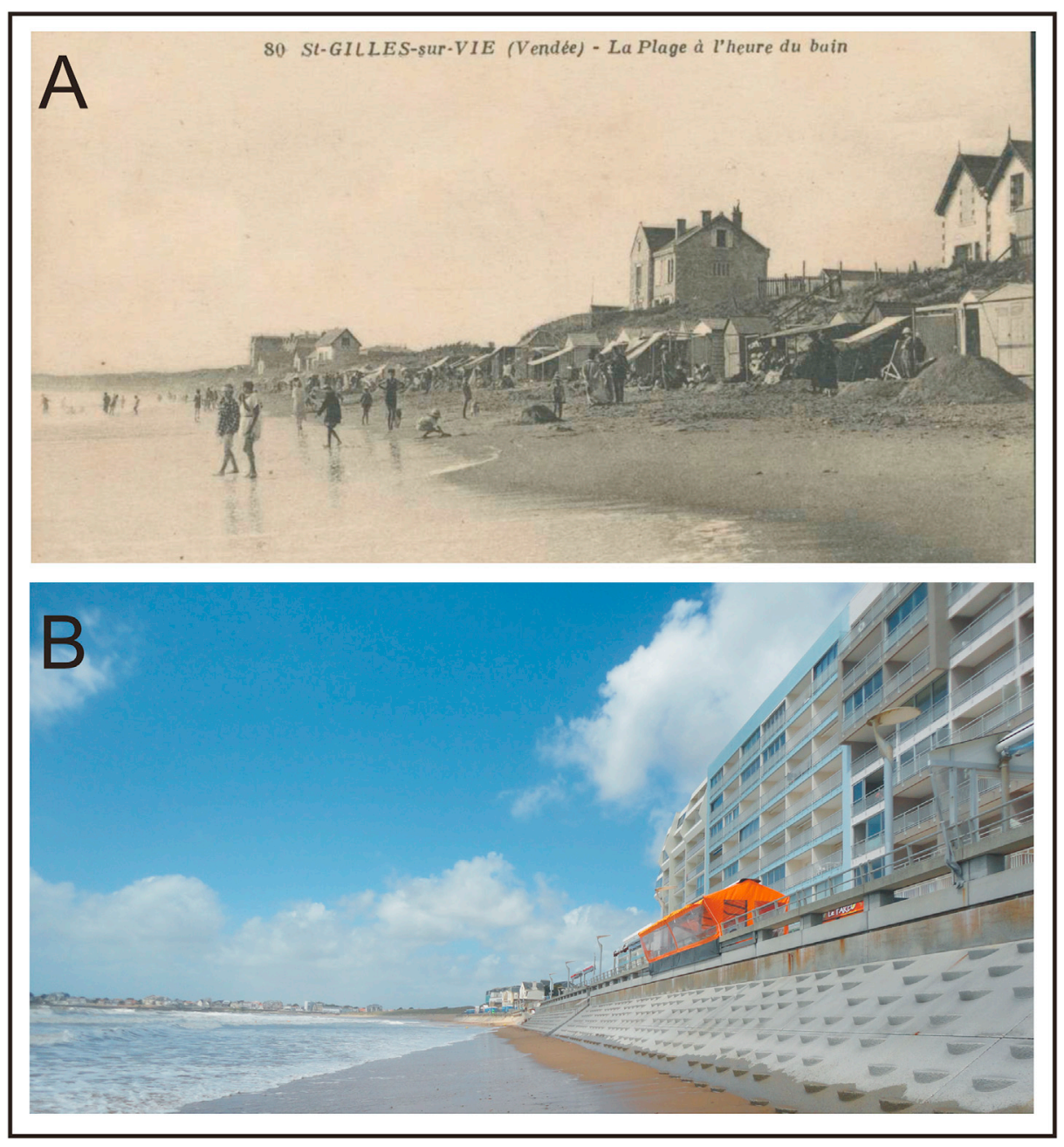

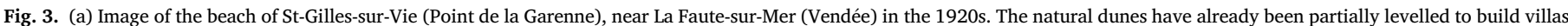

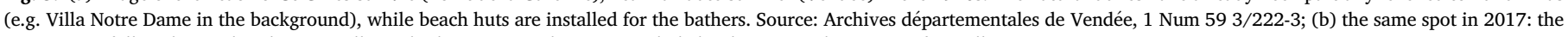
area is now fully urbanized and a sea-wall was built to protect the promenade behind (Source: the Mayor of St-Gilles-sur-Vie). 
exceeding probabilities over time (Salas and Obeysekera, 2013). In general terms, in engineering practice, the return period is assumed to correspond to the mean number of years that it will take for the first occurrence of an event exceeding a given level or forcing condition (e.g., sea level, wave height, etc) to take place. For long return periods (e.g. century scale) and as time passes after an event, there can be a growing "false sense of security" in the population. One may think: "If I build a dike after a flood and 100 years passes, I feel safe because I am protected by a dike", forgetting that the reason for the sense of "safeness" is that the 100 year event may not yet have occurred. Nowadays, authorities use the estimations of modellers and scientists to predict the risks associated to the probability of occurrence of these events. Scientists normally estimate return periods of surges and storms using return periods on the order of 50-100 years and only in some countries such as The Netherlands or Belgium do managers require probabilistic approaches extended to the thousand(s) of year(s) return period.

On the other hand, if we take into account the historical record, namely for the area of La Faute-sur-Mer (four extreme storms in 100 years), we can observe a relatively high frequency of storms with severe impacts. This alerts us to the need of integrating probabilistic determined levels with actual impacts on the ground (resulting from the vulnerability and exposure of the elements). Communication of risk to the exposed population is likely, therefore, to be different, according to the approach used e.g. a historical vs an engineering approach. The historical approach (although not so often concerned with the precise water levels reached) can help to identify and explain the consequences of extreme events and can incorporate a longer timeframe. De facto, today in France, municipalities (at the request of the State) must design their strategy of defence (e.g. dikes) for a time horizon of 50 and 100 years. This horizon lies well inside the historical analysis perspective whereas under the engineering approach it requires the use of some degree of extrapolation.

\subsubsection{Social level}

We provide important guidelines on how to exploit historical datasets of storm records and how they can be merged with recent, high quality observations. Our review strongly builds on arguably the most complete dataset on marine storm impacts available for European Union member states (see Ciavola et al., this issue).

Thus, these historical materials could be used to help establish tools for the management of risks in a contemporary context. This approach can propose solutions for decision-makers based on the experiences of adaptation and resilience seen in the past. For example, historical records can constitute an instrument of mediation between authorities and the local population exposed to these risks. The extremely violent debates between local decision-makers, victims' associations, and the French government after the disaster of the storm Xynthia, perfectly showed that this type of approach would have been able to lessen the incomprehension and tension which continue even nowadays. It would have also allowed a more sustainable and more consensual settling of land (Adger et al., 2005; Allenby and Fink, 2005) in the Atlantic littoral territories instead, for example, of the arbitrary 'black zones' of no construction created by the French government after the disaster of La Faute-sur-Mer. The term refers to the sites where people died. They were bought in by the French state in order to destroy all remaining houses and prohibit reurbanization.

Furthermore, this eminently interdisciplinary approach should encourage collaboration between geographers, sociologists and political scientists. For local people exposed to sea surges, the preservation or the creation of visual testimonies in their daily landscape and the memory of the lessons learned can also contribute directly to a better perception of littoral risks (Fig. 4).

In particular, former societies used the network of bell towers of churches to alert the populations of the islands and the mainland, almost in real time. Whereas recent catastrophes have shown that modern networks of information (internet, mobile telephone) are liable to failure under the high usage levels generated at the time of extreme events, the

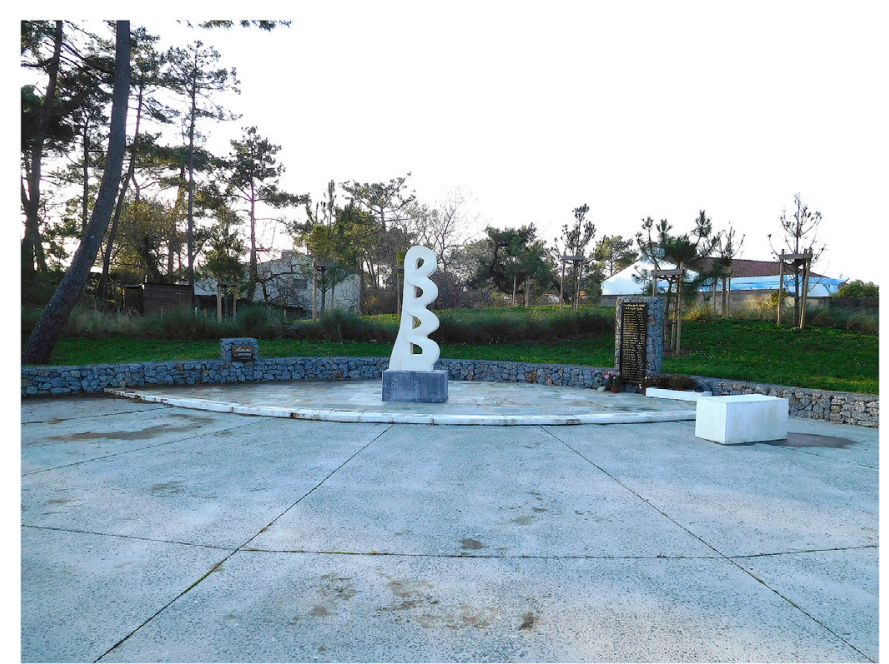

Fig. 4. Stele set up by the association of the victims of La Faute-sur-Mer with a plate on which the names and surnames of the Xynthia storm victims are engraved. Source: E. Garnier, November 2015.

re-use of the bell-towers built in all the European villages and cities using a sound alarm could still be relevant. Whilst such warning systems have been de-commissioned on the North Norfolk coast, it is interesting to note that in Cesenatico, coast of Emilia-Romagna, sirens are still regularly used to warn the population and commercial activities of an imminent flood (Pescaroli and Magni, 2015), despite the existence of an automatic SMS based system. A similar system has been implemented for some time in Venice, with the local population regularly using it to plan commercial activities and access to the town at time of storm surges.

The behaviour of people at risk is also an important factor. During Xynthia, the people exposed to the risk took refuge within safety zones which the archives describe as 'unflooded in living memory'. Others took refuge on the first floor of their houses, a precautionary principle often forgotten today. In Vendée and in Charente-Maritime for example, the majority of houses built over the past 30 years are ground level houses devoid of openings in the roof and equipped with electric shutters and doors, which are clearly prone to failure during a flood.

We believe that a better usage of historical information and local knowledge could effectively support Disaster Risk Reduction strategies. To notice that this concept has been recently expressed by Garnier (2017) when dealing with the impact of Xynthia storm. In cases like the Portuguese site, other authors have produced a historical reconstruction of storm impacts (e.g. Freitas and Dias, 2013), but the work of the current paper for the first time merges long-term analyses with an in-depth inventory of the damages caused by the events. Further work could be the usage of impact indices like the "severity index" of Garnier (2015), accounting for different levels of damage reported in archives (e.g. local vs nationale scale; social impact; etc.)

\section{Conclusions}

The contents of historical archives provide important knowledge relative to the nature of the damage and to the extent of the territories affected by storms. If the instrumental data (wave height, wind speed, water level) are rare before 1900-1950 on the other hand, archives can provide important information on the nature of the damages caused by a historical event. For example the number of uprooted trees, the number of damaged public buildings (city halls, churches, restaurants, etc.) or the location of houses flooded by the sea. As a consequence, it is possible to estimate the impact of historical events developing a "severity index" which is well documented in historical sources. Modellers can then take into account historical events in assessing future levels and patterns of impact/damage, even simply carrying out a 
comparison with historical events. Such a scientific methodology meets the current expectations of European governments, insurers and local policy makers who are particularly sensitive to the social impact of storm surges. As a result, these even imperfect historical results can contribute to improving resilience strategies, clearly demonstrating that the risk associated to storms and storm surges is not new in Europe, even in countries like France, Portugal and Italy where awareness is not as strong as in the United Kingdom. Along the examined coastal zones risk from storms has been increasing during the last century, most probably because of increased human occupation and/or because the level of defence has not been improved or implemented. Despite the fact that historical records tell us that the hazard has always been present, inhabitants and governments typically have short historical memories. This characteristic can lead to the human occupation of areas at risk. By maintaining knowledge of the risks experienced in the past, current littoral societies and their elected representatives can better anticipate urbanization errors, a common feature of most RISC-KIT project case studies.

Finally, the majority of the current inhabitants of European coasts are not original inhabitants because of the continuous migrations towards the coastlines for the last thirty years. Consequently, many of them are not aware of the dangers of the sea. Under these conditions, the presence of flood markings and ex-votos (religious paintings) in the streets and in the churches, or of other types of monuments can raise awareness and thus better prepare inhabitants to future catastrophes or to think more seriously about possible adaptive life strategies in such locations.

\section{Acknowledgements}

This work was supported by the European Community's 7th Framework Programme through the grant to RISC-KIT ("Resilience-increasing Strategies for Coasts - Toolkit"), contract no. 603458 , and by contributions by the partner institutes. We are grateful to Philip Stickler, Cartographic Unit, Department of Geography, University of Cambridge, for drafting Fig. 1.

\section{References}

Adger, W.N., Hughes, T.P., Folke, C., Carpenter, S.R., Rockström, 2005. Social-ecological resilience to coastal disasters. Science 309, 1036-1039.

Albone, J., Massey, S., Tremlett, S., 2007. The archaeology of Norfolk's coastal zone. Result of the national mapping Programme. Engl. Herit. Proj. Nº 2913 (2007), 113-115.

Allenby, B., Fink, J., 2005. Toward inherently secure and resilient societies. Science 309, 1034-1036.

Aminti, P., Cammelli, C., Pelliccia, F., Pranzini, E., 2002. Beach response to a submerged groin field (Marina dei Ronchi, Italy). In: Ozhan, E. (Ed.), Proceedings of the International MedCoast Workshop on Beaches of the Mediterranean and the Black Sea: Dynamics, Regeneration, Ecology and Management, Kusadasi, Turkey, pp. 71-82.

Armaroli, C., Ciavola, P., Perini, L., Lorito, S., Valentini, A., Masina, M., 2012. Critical storm thresholds for significant morphological changes and damage along the EmiliaRomagna coastline. Italy. Geomorphol. 143-144, 34-51.

Baart, F., 2013. Confidence in Coastal Forecasts. PhD Thesis. Technical University of Delft, Delft, The Netherlands.

Baart, F., Bakker, M.A.J., van Dongeren, A., den Heijer, C., van Heteren, S., Smit, M.W.J., van Koningsveld, M., Pool, A., 2011. Using 18th century storm-surge data from the Dutch Coast to improve the confidence in flood-risk estimate. Nat. Hazards Earth Syst. Sci. 11, 2791-2801.

Baxter, P.J., 2005. The east coast Great Flood, 31 January - 1 February 1953: a summary of the human disaster. Philosophical Trans. R. Soc. Lond. Ser. A 363, 1293-1312.

Bertin, X., Bruneau, N., Breilh, J.F., Fortunato, A.B., Karpytchev, M., 2012. Importance of wave age and resonance in storm surges: the case Xynthia. Bay Biscay. Ocean Model 42, 16-30. http://dx.doi.org/10.1016/j.ocemod.2011.11.001.

Breilh, J.F., Chaumillon, E., Bertin, X., Gravelle, M., 2014. How frequent is storm-induced flooding in the central part of the Bay of Biscay. Glob. Planet. Change 122, 161-175.

Brooks, S.M., Spencer, T., Boreham, S., 2012. Mechanisms for cliff retreat in rapidly receding soft-rock cliffs: marine and terrestrial influences. Suffolk coast, U.K. Geomorphol. 153-154, 48-60. http://dx.doi.org/10.1016/j.geomorph.2012.02.007.

Camuffo, D., Secco, C., Brimblecombe, P., Martin-Vide, J., 2000. Sea storms in the Adriatic sea and the western mediterranean during the last millennium. Clim. Change 46 (1), 209-223.
Cappucci, S., Scarcella, D., Rossi, L., Taramelli, A., 2011. Integrated coastal zone management at Marina di Carrara Harbor: sediment management and policy making. Ocean. Coast. Manag. 54, 277-289. http://dx.doi.org/10.1016/ j.ocecoaman.2010.12.006.

Ciavola, P., Ferreira, O., Haerens, P., Van Koningsveld, M., Armaroli, C., 2011. Storm impacts along European coastlines. Part 2: lessons learned from the MICORE project. Environ. Sci. Policy 14, 924-933. http://dx.doi.org/10.1016/j.envsci.2011.05.009.

Ciavola, P., Jiménez, J.A., 2013. Preface the record of marine storminess along European coastlines. Nat. Hazards Earth Syst. Sci. http://dx.doi.org/10.5194/nhess-13-19992013.

Ciavola P., Harley M.D. and den Heijer, C. (this issue) The RISC-KIT storm impact database: a new tool in support of DRR.

Costas, S., Ferreira, O., Martinez, G., 2015. Why do we decide to live with risk at the coast? Ocean. Coast. Manag. 118, 1-11. http://dx.doi.org/10.1016/ j.ocecoaman.2015.05.015.

Cozens-Hardy, B., 1938. Norfolk coastal defences in 1588. Norfolk Archaeol. 26 310-314.

De Zolt, S., Lionello, P., Nuhu, A., Tomasin, A., 2006. The disastrous storm of 4 November 1966 on Italy. Nat. Hazards Earth Syst. Sci. 6, 861-879.

Ferreira, O., Matias, A., Pacheco, A., 2016. the East coast of Algarve: a barrier island dominated coast. Thalassas $32,75-85$.

Freitas, J.G., Dias, J.A., 2013. 1941 windstorm effects on the Portuguese Coast. What lessons for the future? J. Coast. Res. 714-719. SI65.

Gallino, S., Benedetti, A., Onorato, L., 2011. Wave Watching. Lo Spettacolo Delle Mareggiate in Liguria. HOEPLI, Milano.

Garnier, E., Surville, F., 2011. La tempête Xynthia face à l'histoire. Submersions et tsunamis sur les littoraux français du Moyen Age à nos jours (Le Crô̂t vif, Saintes).

Garnier, E., 2015. A historic experience for a strenthened resilience. European societies in front of hydro-meteors 16th-20th centuries. In: Quevauviller, P. (Ed.), Prevention of Hydrometeorological Extreme Events-Interfacing Sciences and Policies. John Wiley \& Sons, Chichester, pp. 3-26.

Garnier, E., 2017. Xynthia, February 2010. Autopsy of a foreseeable catastrophe. In: Quevauviller, P., Ciavola, P., Garnier, E. (Eds.), Management of the Effect of Coastal Storms. ISTE books, London.

Grove, A.T., 1953. IV. The sea flood on the coasts of Norfolk and Suffolk. Geography 38, $164-170$.

Hillen, H.J., 1907. History of the Borough of King's Kynn. East of England Newspaper Company Ltd.

Hooton, J., 1996. The Glaven Ports. A Maritime History of Blakeney, Cley and Wiveton in North Norfolk. Blakeney History Group. Norfolk Record Office, Hall Books KLC, p. 299.

Lamb, H., 1991. Historic Storms of the North Sea, British Isles and Northwest Europe. Cambridge University Press, Cambridge xi $+204 p p$.

Llasat, M.C., Llasat-Botija, M., López, L., 2009. A press database on natural risks and its application in the study of floods in Northeastern Spain. Nat. Hazards Earth Syst. Sci. 9, 2049-2061. http://dx.doi.org/10.5194/nhess-9-2049-2009.

Muir Wood, R., Drayton, M., Berger, A., Burgess, P., Wright, T., 2005. Catastrophe loss modelling of storm-surge flood risk in eastern England. Philosophical Trans. R. Soc. Lond. 363A, 1407-1422.

Muir Wood, R., 2011. The 1941 february 15th windstorm in the iberian peninsula. Trebol Mag. 56, 4-13.

Nordstrom, K.F., Armaroli, C., Jackson, N.L., Ciavola, P., 2015. Opportunities and constraints for managed retreat on exposed sandy shores: examples from EmiliaRomagna, Italy. Ocean. Coast Manage. 104, 11-21.

Perini, L., Calabrese, Deserti, M., Valentini, A., Ciavola, P., Armaroli, C., 2011. Le mareggiate e gli impatti sulla costa in Emilia-Romagna 1946-2010 (ARPA EmiliaRomagna, Bologna, Italy).

Pescaroli, G., Magni, M., 2015. Flood warnings in coastal areas: how do experience and information influence responses to alert services ? Nat. Hazards Earth Syst. Sci. 15 (4), 703-714.

Purchas, A.W., 1965. Some History of Welles-next-to-the-sea and District. East Anglian Magazine Limited, Ipswich.

Pye, K., Blott, S.J., 2006. Coastal processes and morphological change in the Dunwich sizewell area, Suffolk, UK. J. Coast. Res. 22, 453-473.

Salas, J.D.M., Obeysekera, J., 2013. Revisiting the concepts of return period and risk for nonstationary hydrologic extreme events. J. Hydrologic Eng. 19.3, 554-568. http:// dx.doi.org/10.1061/(ASCE)HE.1943-5584.0000820.

Santos, L.F.R., Brito, E.P., Rosa, J.A.P., 1989. A pesca do atum no Algarve, Loulé, published by the Parque Natural da Ria Formosa.

Spencer, T., Brooks, S.M., Evans, B.R., Tempest, J.A., Möller, I., 2015. Southern North Sea storm surge event of 5 December 2013; Water levels, waves and coastal impacts. Earth-Science Rev. 146, 120-145.

Steers, J.A., 1953. The east coast floods, January 31-February 1 1953. Geogr. J. 119, 280-295 (and discussion 295-298).

Steers, J.A., 1960. Physiography and evolution: the physiography and evolution of Scolt Head island. In: Steers, J.A. (Ed.), Scolt Head Island, second ed. Heffers, Cambridge, pp. 12-66.

Steers, J.A., Bayliss-Smith, T.P., Stoddart, D.R., Spencer, T., Durbridge, P.M., 1979. The storm surge of 11 January 1978 on the east coast of England. Geogr. J. 145, 192-205.

Tidal Harbours Commission, 1846. Second Report of the Commissioners, with Minutes of Evidence, Appendices, Supplement and Index. W. Clowes \& Sons, London.

Trigo, I.F., Davies, T.D., 2002. Meteorological conditions associated with sea surges in Venice: a 40 year climatology. Int. J. Climatol. 22, 787-803. http://dx.doi.org/ $10.1002 /$ joc.719. 
Uppala, S.M., Kallberg, P.W., Simmons, A.J., Andrae, U., Bechtold, V.D., Fiorino, M., Gibson, J.K., Haseler, J., Hernandez, A., Kelly, G.A., Li, X., Onogi, K., Saarinen, S., Sokka, N., Allan, R.P., Andersson, E., Arpe, K., Balmaseda, M.A., Beljaars, A.C.M., Van De Berg, L., Bidlot, J., Bormann, N., Caires, S., Chevallier, F., Dethof, A.,

Dragosavac, M., Fisher, M., Fuentes, M., Hagemann, S., Holm, E., Hoskins, B.J., Isaksen, L., Janssen, P.A.E.M., Jenne, R., McNally, A.P., Mahfouf, J.F., Morcrette, J.J., Rayner, N.A., Saunders, R.W., Simon, P., Sterl, A., Trenberth, K.E., Untch, A., Vasiljevic, D., Viterbo, P., Woollen, J., 2005. The ERA-40 re-analysis. Q. J. R. Meteorol. Soc. 131, 2961-3012. http://dx.doi.org/10.1256/qj.04.176.
Van Dongeren, A., Ciavola, P., Martinez, G., Viavattene, C., Bogaard, T., Ferreira, O., Higgins, R., McCall, R. (this issue) Introduction to RISC-KIT: resilience-increasing strategies for coasts.

Vinet, F., Lumbroso, D., Defossez, S., Boissier, L., 2012. A comparative analysis of the loss of life during two recent floods in France : the sea surge caused by the storm Xynthia and the flash flood in Var. Nat. Hazards 61, 1179-1201.

Wolf, J., Flather, R.A., 2005. Modelling waves and surges during the 1953 storm. Philosophical Trans. R. Soc. Lond. 363A, 1359-1375. 